\title{
A World Galloping into Breathlessness
}

There is still much to learn about chronic obstructive pulmonary disease (COPD), but some facts about COPD we will never be able to grasp because they are just too breathtaking. Half of all regular cigarette smokers will eventually die due to their habit [1]. What makes these people follow the ghostly Marlboro man faithfully unto their own death? The costs for the tobacco epidemic are enormous [2,3] and in the foreseeable future they appear to be skyrocketing in the developed countries [4] despite a presumed decrease in cigarette smoking there. In the developing countries the bitter aftermath of the tobacco epidemic is delayed, but eventually the glamorous glow will turn into an explosive demand for medical care and the poor health resources will be put under further strain. In 1993, USD 50 billion were spent in the United States on medical care attributable to tobacco smoking [2], and in the same year the direct treatment costs for COPD were approximately USD 14.7 billion, and the indirect costs for COPD were estimated at USD 9.2 billion [3].

Epidemiological research and long-term follow-up studies have been powerful tools in delineating the importance of COPD in different populations. There is nevertheless a continuous need for further cross-sectional and longitudinal studies on COPD, not the least in the developing countries, so that the results of various efforts to reduce its causes and prevalence can be determined.

There are similarities and dissimilarities between bronchial asthma and COPD. The prevalence of both conditions has increased markedly world-wide, particularly in countries adopting a 'western life-style', and they both constitute major health problems. However, while the causes of the epidemic increase in asthma prevalence over the last decades are largely unknown, the most import cause of COPD is well established. Air pollution may be the common denominator for some cases of asthma and COPD but appears not to be the most important factor for either disease. The reasons why some people are more susceptible to developing COPD than others are also largely unknown, while a hereditary component of asthma has been well known among clinicians for ages. Events, such as maternal smoking before or after birth, may, however, be relevant to both diseases. Both asthma and COPD are related to inflammatory processes in the airways. While inhaled corticosteroids have revolutionized the treatment of asthma, no similarly efficacious treatment of the inflamed bronchi or bronchioli in patients with COPD has yet been put on the market. The multitude of challenges in COPD research are obvious!

The 2001 Thematic Review Series aims at providing the readers of Respiration the state of the art and future direction of COPD research, knowledge and management. The first of the six reviews is on epidemiology of COPD and comes from a well-known Italian research group: Viegi et al. [5] describe the risk factors for developing COPD, its prevalence and consequences on society. They send out a call for a world-wide consensus on the definition of COPD, the lack of which $[6,7]$ makes appropriate comparative population studies difficult to perform.

\begin{tabular}{ll}
\hline KARGER & ( ) 2001 S. Karger AG, Basel \\
$\begin{array}{l}\text { Fax +41 61 306 1234 } \\
\text { E-Mail karger@karger.ch } \\
\text { www.karger.com }\end{array}$ & $\begin{array}{l}\text { Accessible online at: } \\
\text { www.karger.com/journals/res }\end{array}$
\end{tabular}


The subsequent reviews will focus on the pathogenesis and pathology of COPD, how to optimally assess COPD, medical and surgical treatment options, and finally on the expected future advances in the therapy of COPD. The authors of these COPD review articles are distinguished colleagues in the forefront of COPD research or management. Their articles will increase our understanding, make the daily work with COPD patients even more interesting, and stimulate us to continue our efforts.

Per M. Gustafsson, MD, PhD Associate Editor

\section{References}

1 Doll R, Peto R, Wheatley K, et al: Mortality in relation to smoking: 40 years' observation on male British doctors. Br Med J 1994;309:901911.

2 US Centers for Disease Control and Prevention. Medical-care expenditures attributable to cigarette smoking - United States, 1993. Mor Mortal Wkly Rep CDC Surveill Summ 1994;43:469-472.

3 Sullivan SD, Ramsey SD, Lee TA: The economic burden of COPD. Chest 2000;117:5-9.
4 Rutten-van Molken MP, Postma MJ, Joore MA, et al: Current and future medical costs of asthma and chronic obstructive pulmonary disease in The Netherlands. Respir Med 1999;93: 779-787.

5 Viegi G, Scognamiglio A, Baldacci S, Pistelli F, Carrozzi L: Epidemiology of chronic obstructive pulmonary disease (COPD). Respiration 2001;68:4-19.
6 American Thoracic Society: Standards for the diagnosis and care of patients with chronic obstructive pulmonary disease (COPD) and asthma. Am Rev Respir Dis 1987;136:225244.

7 Siafakas NM, Vermeire P, Pride NB, Paoletti P, Gibson J, Howard P, Yernault JC, Decramer M, Higenbottam T, Postma DS, et al: Optimal assessment and management of chronic obstructive pulmonary disease (COPD). The European Respiratory Society Task Force. Eur Respir J 1995;8:1398-1420. 